\title{
Nephron-sparing Surgery without Angioembolization in Giant Angiomyolipoma: Is it Feasible?
}

\author{
Dev Anjiyomiyolipomda Anjiyoembolizasyon OImadan Nefron Koruyucu Cerrahi: \\ Uygulanabilir mi?
}

\author{
(D) Ankur Arya, (D) Hardev Bhatyal, (D) Vineet Narang, (D) Suruchi Agarwal \\ BLK Super Speciality Hospital, Clinic of Urology, Delhi, India
}

\begin{abstract}
Varying sizes of renal angiomyolipoma (AML) have been reported in the literature, with the general consensus that a size greater than $10 \mathrm{~cm}$ can be termed a giant AML. Our patient presented with increasing abdomen girth since last 3 years. Contrast-enhanced computed tomography scan of the abdomen confirmed the presence of "AML" arising from the upper and mid pole of the right kidney with similar small foci in the contralateral kidney. The patient underwent nephron-sparing surgery with preserving the right lower pole with enucleation of multiple small foci in the right kidney. The surgical specimen, which was confirmed to be AML histopathologically, was $40 \mathrm{~cm} \times 20 \mathrm{~cm} \times 15 \mathrm{~cm}$ in size and $7000 \mathrm{~g}$ in weight. This represents the case of the largest AML with a dimension of up to $40 \mathrm{~cm}$ and managed by nephron-sparing surgery without prior angioembolization. AML larger than $10 \mathrm{~cm}$ is usually considered to be giant AML in the literature.
\end{abstract}

Keywords: Angioembolization, Giant angiomyolipoma, Nephron-sparing surgery, Renal angiomyolipoma, Nephrectomy

Öz

Literatürde çeşitli boyutlarda renal anjiyomiyolipom olguları bildirilmiştir ve $10 \mathrm{~cm}$ 'den daha büyük olanlar için dev AML terimi genel ortak görüştür. Olgumuz, son üç yıldır artan karın şişliği ile başvurdu. Kontrastlı batın tomografisi hem sol böbrekte küçük ve çok odaklı hem de sağ böbreğin üst ve orta bölümünden köken alan büyük boyutlarda anjiyomiyolipomlar saptadı. Sağ böbreğin orta ve üst bölümüne uygulanan parsiyel nefrektomiye ek olarak alt kutuptaki küçük odaklara da enükleasyon uygulanarak, nefron koruyucu cerrahi yapıldı. Cerrahi örnek $40 \mathrm{~cm} \times 20 \mathrm{~cm} \times 15 \mathrm{~cm}$ boyutlarında ve $7000 \mathrm{~g}$ ağırlığında olup, histopatolojik açıdan AML olduğu doğrulandı. Bu, 40 cm'ye kadar bir boyuta sahip en büyük AML olgusudur ve öncesinde anjiyoembolizasyon olmaksızın nefron koruyucu cerrahi yapılmıştır. Boyutu genellikle $10 \mathrm{~cm}$ 'den büyük olan AML, literatürde dev AML olarak kabul edilir. Anahtar Kelimeler: Anjiyoembolizasyon, Dev anjiyomiyolipom, Nefron koruyucu cerrahi, Renal anjiyomiyolipom, Nefrektomi

\section{Introduction}

Renal angiomyolipoma (AML) is a benign tumor composed of adipose tissue, abnormal blood vessels and smooth muscle. AML is usually diagnosed incidentally on ultrasound but symptoms may vary from flank pain, palpable flank mass and hematuria to life-threatening hemorrhage (52\%-91\%) especially in those larger than $4 \mathrm{~cm}$. Giant AML is usually managed by transarterial embolization (TAE), partial nephrectomy or total nephrectomy as described in the literature. Our case represents the largest AML with a dimension of up to $40 \mathrm{~cm}$ which was managed by nephron-sparing surgery in the form of partial nephrectomy without prior embolization.

\section{Case Presentation}

A 35-year-old female patient presented with bloating sensation and increasing abdomen girth since last 3 years. Ultrasound

Correspondence: Ankur Arya MD, BLK Super Speciality Hospital, Clinic of Urology, Delhi, India

Phone: +919594976834 E-mail: drankurarya8@gmail.com ORCID-ID: orcid.org/0000-0002-0479-873X

Received: 16.05.2017 Accepted: 28.07.2017

Cite this article as: Arya A, Bhatyal H, Narang V, Agarwal S. Nephron-sparing Surgery without Angioembolization in Giant Angiomyolipoma: Is it Feasible? J Urol Surg 2018;5(3):191-193.

๑Copyright 2018 by the Association of Urological Surgery / Journal of Urological Surgery published by Galenos Publishing House. 
revealed a large hyperechoic and heterogeneous mass arising from the right kidney and extending toward other side of the abdomen. Her serum creatinine level was $0.8 \mathrm{mg} / \mathrm{dL}$. Contrast-enhanced computed tomography (CT) scan of the abdomen confirmed the presence of AML of size $35 \mathrm{~cm} \times 18 \mathrm{~cm}$ arising from the upper and mid pole of the right kidney with multiple feeding vessels and similar small foci in the contralateral kidney (Figure 1). Magnetic resonance imaging of the brain revealed no signs of tuberous sclerosis and that were suggestive of sporadic AML. The possible treatment options including nephron-sparing surgery and total nephrectomy were explained to the patient. Midline abdomen incision was taken from the xiphisternum to the pubic symphysis. A large mass arising from the upper and mid pole of the right kidney with multiple small foci in the lower pole was seen. The mass was mobilized and delivered partly outside the abdomen with intact vascularity for easy access to the renal pedicle from the inferior aspect. The renal pedicle was isolated and encircled by a vessel loop (Figure 2). Right partial nephrectomy involving the upper and mid poles was done with excision of 3 superficial lesions in the lower pole and preserving the remaining lower pole of the right kidney. Renal defect was closed with interrupted 2/0 vicryl sutures over an absorbable hemostat (Surgicel) after closure

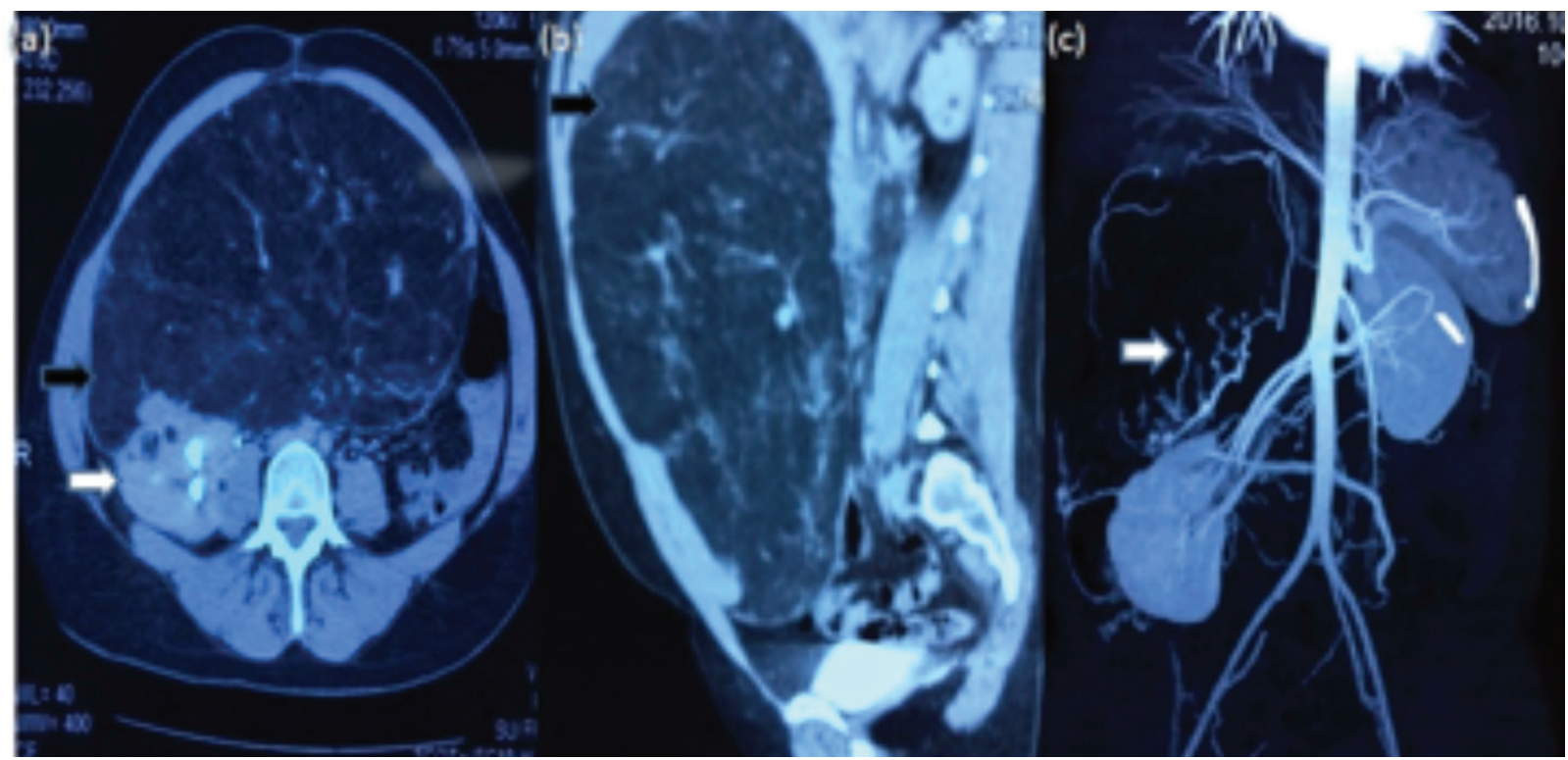

Figure 1. Computed tomography scan, a) Transverse, b) Saggital image showing giant angiomyolipoma (black arrow) arising from upper and mid pole of right kidney and normal right lower pole (white arrow) with multiple small foci of angiomyolipoma, c) Computed tomography angiography demonstrates giant angiomyolipoma with multiple feeding vessels (white arrow)

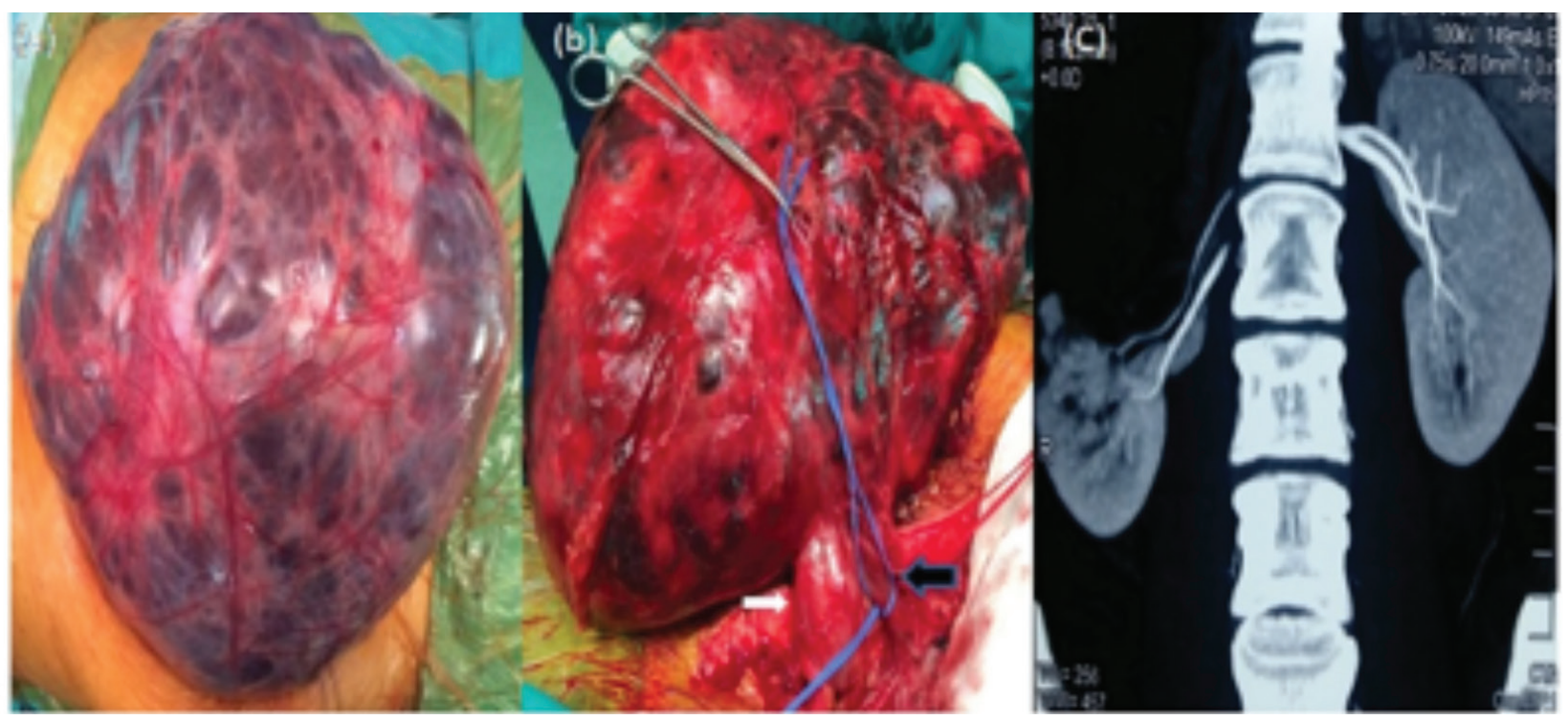

Figure 2. Intraoperative finding of a) giant angiomyolipoma delivered out of the abdomen, b) Giant angiomyolipoma with normal remaining right lower pole (white arrow) and renal pedicle (black arrow), c) Postoperative computed tomography angiography demonstrates normal functioning remaining right lower pole with intact vascularity and no recurrence 
of the collecting system separately. The total warm ischemia time was 10 minutes with no major blood loss intraoperatively. The patient was discharged on day 7 with a serum creatinine level of $0.9 \mathrm{mg} / \mathrm{dL}$. The mass was grossly measured $40 \times 20 \times 15 \mathrm{~cm}$ and weighed $7000 \mathrm{~g}$. Histopathology of the specimen confirmed the presence of AML. CT renal angiography revealed normal functioning of the remaining right lower pole $(6.4 \times 4.1 \mathrm{~cm})$ with no recurrence (Figure 2) after 6 months.

Written informed consent was obtained by participant.

\section{Discussion}

AML measuring over $10 \mathrm{~cm}$ is considered giant AML. AML larger than $4 \mathrm{~cm}$ usually requires treatment due to great risk of bleeding. Treatment could vary from TAE to surgical intervention in the form of either nephron-sparing surgery or total nephrectomy. TAE may obviate the need of emergency surgical intervention in the form of total nephrectomy especially in stable patients with retroperitoneal hemorrhage associated with giant AML. However, this comes with the risk of Postembolization syndrome. These patients can be managed later on by elective nephron-sparing surgery due to the decrease in size of AML (30\%-50\%) (1). We managed our patient with giant AML by nephron-sparing surgery without prior embolization to avoid the risk of Post-embolization syndrome which is observed especially in large tumors. Giant AML usually managed by total nephrectomy (2). We should always attempt to preserve the renal function by nephron-sparing surgery in giant AML because they mostly arise from a small portion of normal kidney $(3,4)$. Very few studies are there with regards to nephron-sparing surgery in giant AML with low complication rates of up to $12 \%$ and low local recurrence rates (5). There have been case reports of giant AML managed by preoperative embolization followed by partial nephrectomy $(6,7)$. Very few case reports of giant AML managed by partial nephrectomy without angioembolization have been described in the literature, but the size of AML in that case was $24 \mathrm{~cm}(8,9)$. Our case represent the largest AML $(40 \times 20 \times 15$ $\mathrm{cm}$ ) ever reported which was managed by nephrectomy with excision of multiple lesions in the remaining kidney without the need for prior embolization. AML could be sporadic or familial in association with tuberous sclerosis complex (TSC). It is very difficult to carry out partial nephrectomy in familial AML due to multiple and larger lesions. AML with TSC is usually associated with upregulation of mammalian target of rapamycin (mTOR) pathway. mTOR inhibitors, such as sirolimus and everolimus, should be considered in the management of familial AML prior to nephron-sparing surgery as these agent decrease the size of the lesion and make the patient amenable to nephron-sparing surgery which is otherwise difficult to carry out.

\section{Ethics}

Informed Consent: Written informed consent was obtained by participant.

Peer-review: Internally peer-reviewed.

\section{Authorship Contributions}

Surgical and Medical Practices: A.A., H.B., V.N., S.A., Concept: A.A., H.B., V.N., S.A., Design: A.A., H.B., V.N., S.A., Data Collection or Processing: A.A., H.B., V.N., S.A., Analysis or Interpretation: A.A., H.B., V.N., S.A., Literature Search: A.A., H.B., V.N., S.A., Writing: A.A., H.B., V.N., S.A.

Conflict of Interest: No conflict of interest was declared by the authors.

Financial Disclosure: The authors declared that this study received no financial support.

\section{References}

1. Sooriakumaran $P_{\text {, Gibbs }}$, Coughlin $G$, Attard V, Elmslie $F$, Kingswood $C$ Taylor J, Corbishley C, Patel U, Anderson C. Angiomyolipomata: challenges, solutions and future prospects based on over 100 cases treated. BJU Int 2010;105:101-106.

2. Taneja R, Singh DV. Giant renal angiomyolipoma: unusual cause of huge abdominal mass: J Clin Imaging Sci 2013;3:56.

3. Weight CJ, Lieser G, Larson BT, Gao T, Lane BR, Campbell SC, Gill IS, Novick AC, Fergany AF. Partial nephrectomy is associated with improved overall survival compared to radical nephrectomy in patients with unanticipated benign renal tumours. Eur Urol 2010;58:293-298.

4. Ljungberg $B$, Hedin 0 , Lundstam $S$, Warnolf $\AA$, Mandahl Forsberg $A$, Hjelle KM, Stief CG, Borlinghaus C, Beisland C, Staehler M. Nephron Sparing Surgery Associated with Better Survival than Radical Nephrectomy in Patients Treated for unforeseen Benign Renal Tumors. Urology 2016;93:117-121.

5. Boorjian SA, Frank I, Inman B, Lohse CM, Cheville JC, Leibovich BC, Blute $M L$. The role of partial nephrectomy for the management of sporadic renal angiomyolipoma. Urology 2007;70:1064-1068.

6. Singla A, Chaitanya Arudra SK, Bharti N. Giant sporadic renal angiomyolipoma treated with nephron-sparing surgery. Urology 2009;74:294-295.

7. Albersheim-Carter J, Klein M, Murugan P, Weight CJ. Partial Nephrectomy for a Massive Sporadic Renal Angiomyolipoma: Case Report and Review of the Literature. Case Rep Urol 2016;2016:3420741.

8. Coskuner ER, Ozkan B, Yalcin V. The Role of Partial Nephrectomy without Arterial Embolization in Giant Renal Angiomyolipoma. Case Rep Med 2012;2012:365762.

9. Lim EJ, Consigliere DT, Tiong HY. Successful management of a Giant Angiomyolipoma with partial nephrectomy. Sciedu Press Journals Online 2016;2:19-22. 